\title{
PENGARUH PEMBERIAN EKSTRAK DAUN KEPEL (Stelechocarpus burahol) SEBAGAI FEED ADDITIVE HERBAL TERHADAP RETENSI NITROGEN DAN AMONIA EKSKRETA AYAM BROILER
}

\author{
(The Impact of Kepel Leaf (Stelechocarpus burahol) Extract as Feed Additive on Nitrogen \\ Retention and Ammonia Excretion of Broiler Chickens)
}

\author{
Riki Saumi Nuryana, Abun, dan Eulis Tanti Marlina \\ Program Pendidikan Magister Program Studi Ilmu Peternakan Konsentrasi Nutrisi dan Makanan Ternak \\ Fakultas Peternakan Universitas Padjadjaran \\ Jalan Raya Bandung - Sumedang Km 21 Jatinangor, Sumedang 45363. \\ email : saumi.nuryana@gmail.com
}

\begin{abstract}
The objective of this study was to determine the effect of giving Kepel (Stelechocarpus burahol) leaf extract on the nitrogen retention and ammonia excretion of broiler chickens. This study used 100 Day Old Chick (DOC) broilers with a maintenance period of 30 days. The ration was derived from ingredients compiled into basal feed containing PK 21.50\% and EM 3,032 cal/g. The experimental design used was a Completely Randomized Design (CRD), the treatment of 4 doses of Kepel leaf extract in rations was repeated 5 times. The treatment given in the ration consisted of $R_{0}=$ basal ration + dosage of kepel leaf extract $0 \%, R_{1}=$ basal ration + dosage of kepel leaf extract $0.15 \%, R_{2}=$ basal diet + dosage of kepel leaf extract $0.30 \%$, and $R_{3}=$ basal ration + dosage of kepel leaf extract $0.45 \%$. The parameters observed were nitrogen retention and ammonia value of broiler chicken excreta. The research data were processed using statistical analysis of variance and continued with the Duncan test to see the significance of the inter-treatments. The results showed that the administration of $0.30 \%$ kepel leaf extract during the maintenance period resulted in the highest nitrogen retention value and the lowest ammonia content in broiler chicken excreta.
\end{abstract}

Keywords : Kepel leaf extract, Nitrogen retention, Ammonia excreta, Broiler chickens

\begin{abstract}
ABSTRAK
Tujuan penelitian ini untuk mengetahui pengaruh pemberian ekstrak daun kepel (Stelechocarpus burahol) terhadap retensi nitrogen dan amonia ekskreta ayam broiler. Penelitian ini menggunakan 100 ekor ayam broiler umur sehari dengan masa pemeliharaan 30 hari. Ransum basal yang mengandung PK 21,50\% dan EM 3032 kal/g. Rancangan percobaan yang digunakan adalah Rancangan Acak Lengkap (RAL), perlakuan 4 dosis ekstrak daun kepel dalam ransum diulang sebanyak 5 kali. Perlakuan yang diberikan dalam ransum terdiri atas $\mathrm{R}_{0}=$ Ransum basal, $\mathrm{R}_{1}=$ Ransum basal + dosis ekstrak daun kepel 0,15\%, $R_{2}=$ Ransum basal + dosis ekstrak daun kepel 0,30\%, dan $R_{3}=$ Ransum basal + dosis ekstrak daun kepel 0,45\%. Parameter yang diamati adalah nilai retensi nitrogen dan amonia ekskreta ayam broiler. Data diolah menggunakan analisis statistik sidik ragam dan dilanjutkan dengan Uji Duncan untuk melihat signifikansi dari antar perlakuan. Hasil penelitian menunjukkan bahwa pemberian ekstrak daun kepel 0,30\% selama masa pemeliharaan menghasilkan nilai retensi nitrogen tertinggi dan kandungan amonia terendah dalam ekskreta ayam broiler.
\end{abstract}

Kata kunci : Ekstrak daun kepel, Retensi nitrogen, Amonia ekskreta, Ayam broiler

\section{PENDAHULUAN}

Ayam broiler Final Stock merupakan ternak unggas yang memiliki produktivitas daging sebagai sumber protein hewani untuk bahan pangan manusia. Produksi ayam broiler dapat dilihat dari beberapa aspek penting antara lain performans, nutrisi pakan dan status kesehatan. Aspek nutrisi pada pakan komersil dalam pemeliharaan ayam broiler memiliki kualitas yang baik untuk memenuhi kebutuhan hidup pokok dan produksi. Ayam broiler merupakan salah satu jenis ternak yang menghasilkan ekskreta dengan amonia yang relatif lebih tinggi 
dibanding ternak lainnya, karena penyerapan protein lebih tinggi untuk kebutuhan hidup. Konsentrasi $\mathrm{NH}_{3}$ meningkat sejalan dengan meningkatnya kelembaban, $\mathrm{pH}$, dan temperatur kandang, serta populasi mikroorganisme. Solusi untuk menekan dampak negatif amonia terhadap produktivitas serta aman pada tubuh ayam broiler maupun manusia yang mengkonsumsinya yaitu menggunakan zat imbuhan pakan seperti feed additive herbal dalam ransum.

Feed additive berupa antibiotikdalam ransum yang berfungsi sebagai agen penghambat pertumbuhan bakteri patogen telah digunakan secara luas pada pemeliharaan broiler, namun demikian, telah terbit aturan pembatasan penggunaannya karena dampak berupa residu yang dapat membahayakan kesehatan manusia yang mengkonsumsi daging ayam broiler tersebut. Salah satu solusi pengganti antibiotik adalah penggunaan feed additive herbal yang mengandung senyawa antibakteri. Penambahaan feed additive herbal menjadi solusi untuk peternakan ayam broiler dalam mengatasi penyakit yang timbul karena produksi amonia dalam ekskreta yang melebihi ambang batas. Hal ini diakibatkan Enterobacteria dalam usus halus mengganggu laju penyerapan nitrogen pakan sebagai zat penting dalam aspek produksi ayam broiler selama pemeliharaan. Bakteri patogen dalam usus halus memerlukan nitrogen untuk tumbuh dan berkembangbiak sehingga nitrogen pakan yang seharusnya diserap oleh tubuh ayam broiler menjadi tidak optimal. Oleh karena itu, mekanisme kerja senyawa flavonoid akan sangat berpengaruh menurunkan jumlah bakteri pathogen dalam usus halus ayam broiler. Mekanisme kerja senyawa flavonoid yaitu menyebabkan koagulasi atau penggumpalan protein sel bakteri pathogen. Protein yang menggumpal mengalami denaturasi sehingga tidak berfungsi lagi (Dwijoseputro, 2005).

Produksi toksin dari Enterobacteria dapat menimbulkan infeksi mukosa usus halus, dan berdampak pada tidak optimalnya penyerapan nitrogen pakan ke dalam tubuh sehingga banyak nitrogen pakan yang ikut terbuang bersama ekskreta dalam bentuk amonia. Amonia yang berlebihan selama pemeliharaan dapat menimbulkan inflamasi atau peradangan pada organ pernafasan sehingga sekresi lendir yang berlebihan oleh sel goblet pada bronkus. Proses pembentukan amonia di dalam usus halus dilakukan oleh beberapa jenis bakteri yaitu bakteri gram negatif, Clostridia, dan Enterobacteria) (Vince \& Burridge, 1980). Amonia merupakan senyawa yang bersifat iritan terutama terhadap saluran pernafasan. Amonia dapat mempengaruhi mekanisme pertahanan diri pada saluran pernafasan. Permukaan epitel trakhea dan bronkhus akan mengalami deskuamasi sehingga partikel - partikel udara lebih mudah masuk kedalam saluran pernafasan (Peters dan LeDuc, 1999).

Ekstrak daun kepel (Stelechocarpus burahol) menjadi salah satu alternatif karena terdapat kandungan antibakteri dalam bentuk senyawa proantosianidin (tanin terkondensasi) yang berfungsi memproteksi dinding usus halus terhadap toksin yang diekskresikan oleh Enterobacteria. Konsentrasi senyawa proantosianidin sebagai salah satu antimikroba yang terkandung dalam ekstrak daun kepel dengan metode maserasi selama 48 jam yaitu sebesar 27,59\% hasil dari analisis alat LCMS (Puslabfor, 2019). Senyawa tanin sebagai antibakteri juga dapat menghambat enzim reverse transkriptase dan DNA topoisomerase yang berperan dalam proses multiplikasi bakteri sehingga sel bakteri tidak dapat terbentuk dan memperbanyak diri (Mukhriani dkk, 2014). Proantosianidin bekerja sebagai antibakteri dengan menghambat pembentukan dan menyebabkan lisisnya ikatan polipeptida dinding sel bakteri gram negatif serta merusak lapisan peptidoglikan pada bakteri gram positif. Proantosianidin dapat mengurangi pembentukan gas amonia karena nitrogen bebas yang akan dimanfaatkan bakteri patogen diikat oleh senyawa proantosianidin untuk dimanfaatkan oleh tubuh ayam. Kondisi saluran pencernaan yang baik dan sehat sangat berpengaruh pada nilai retensi nitrogen yang akan diserap dalam tubuh ternak menjadi lebih optimal(Treviño dkk, 2000). Penelitian ini bertujuan untukmengetahui pengaruh penambahan ekstrak daun kepel terhadapnilai retensi nitrogen dankandungan amonia ekskreta ayam broiler diakhir masa pemeliharaan.

\section{MATERI DAN METODE}

Penelitian dilaksanakan pada bulan Agustus - Oktober 2019 di Kandang Test Farm Print-G, Fakultas MIPA, Universitas Padjadjaran, Sumedang. Bahan yang digunakan yaitu 100 ekor Day Old Chick (DOC) ayam broiler strain CP 707 dengan bobot awal rata-rata 38+1,16gram dan eksktrak daun kepel sebanyak 250 gram. Ayam broiler dipelihara selama 30 hari dalam kandanglitter yang berukuran $1 \mathrm{~m} \times 1 \mathrm{~m}$ dan 
setiap unit kandang berisi 5 ekor ayam. Peralatan yang dibutuhkan dalam penelitian yaitu thermohigrometer, instalasi listrik, timbangan digital, tempat pakan dan minum, alumunium foil, asam borat $10 \%$, plastic crap .

\section{Rancangan dan tahap persiapan}

Tahap persiapan dilakukan dengan membuat ekstrak dari $5 \mathrm{~kg}$ daun kepel kering di ekstraksi secara maserasi selama 48 jam menggunakan larutan Ethanol 70\% menggunakan alat Rotatory Evaporator. Setelah waktu maserasi 48 jam dihasilkan 250 gram rendemen kental.

Penelitian ini disusun berdasarkan Rancangan Acak Lengkap (RAL) dengan 4 perlakuan penambahan ekstrak daun kepel dan 5 ulangan sehingga terdapat 20 unit percobaan, setiap unit percobaan terdiri dari 5 ekor ayam. Perlakuan yang diberikan yaitu :

$\mathrm{R}_{0}$ : Ransum basal; $\mathrm{R}_{1}$ : Ransum basal + 0,15\% ekstrak daun kepel; $R_{2}$ : Ransum basal + $0,30 \%$ ekstrak daun kepel; $R_{3}$ : Ransum basal + $0,45 \%$ ekstrak daun kepel.

Tahap penyusunan ransum dilakukan dengan menyiapkan bahan-bahan pakan seperti jagung kuning, bungkil kedelai, dedak padi halus, tepung ikan, tepung tulang, kapur, minyak kelapa, DL-Methionine, L-Lysine. Penyusunan ransum didasarkan pada perhitungan kebutuhan nutrien ayam pada fase starter dan finisher kemudian dilakukan penimbangan dan pencampuran bahan pakan sesuai komposisi yang telah dibuat. Jenis bahan pakan dan persentase penggunaan bahan pakan dalam ransum perlakuan disajikan pada Tabel 1.

\section{Tahap pemeliharaan}

Sebanyak 100 ekor ayam broiler umur sehari ditempatkan dalam 20 unit kandang percobaan yang diisi 5 ekor ayam dan dipelihara selama 30 hari. Ayam broiler diberikan pakan basal sesuai masing-masing perlakuan hingga akhir masa pemeliharaan. Pemberian pakan dan minum dilakukan secara ad libitum. Pencatatan pemberian pakan dilakukan setiap hari dan penimbangan sisa pakan dilakukan setiap minggu untuk menghitung konsumsi pakan rata-rata. Penimbangan bobot badan dilakukan setiap seminggu sekali untuk memperoleh pertambahan bobot badan harian (PBBH). Vaksinasi dilakukan masing-masing pada umur 4 hari (ND), umur 14 hari (IBD Gumboro), dan umur 21 hari (ND).

\section{Tahap pengambilan data}

Pengambilan data penelitian dilakukan dengan cara mengambil ekskreta ayam broiler pada hari ke-30. Pengambilan ekskreta ayam dari tiap ulangan dilakukan secara acak dengan menempatkan ayam pada kandang terpisah, kemudianekskreta yang diambil sebanyak 10 gram menggunakan sendok alumunium, ekskreta yang telah diambil kemudian dimasukkan ke dalam corong alumunium foillalu disemprotkan asam borat $10 \%$ dan dimasukan kedalam plastic crap tutup rapat bertujuan agar amonia ekskreta tidak

Tabel 1. Bahan Pakan, Persentase Penggunaan dan Kandungan Nutrien Pakan Basal

\begin{tabular}{lc}
\hline Bahan pakan & Persentase $(\%)$ \\
\hline Jagung kuning & 55,39 \\
Dedak halus & 6,68 \\
Bungkil kedelai & 31,01 \\
Tepung ikan & 2,75 \\
Minyak kelapa & 1,72 \\
Tepung tulang & 1,00 \\
Kapur & 1,00 \\
L-Lysine & 0,22 \\
DL-Methionine & 0,22 \\
\hline Total & $\mathbf{1 0 0}$ \\
\hline Energi metabolis (kkal/kg) & $\mathbf{3 0 2 3}$ \\
\hline Protein kasar (\%) & $\mathbf{2 1 , 5 0}$ \\
\hline
\end{tabular}


menguap. Analisis sampel ekskreta dilakukan di Laboratorium Kimia Makanan Ternak dan Ruminansia, Fakultas Peternakan, Universitas Padjadjaran, Sumedang. Perhitungan nilai retensi nitrogen menggunakan rumus metode Maynard dan Loosli (1962), sebagai berikut :

$$
\mathrm{RN}(\%)=\left[\frac{\mathrm{NI}-\mathrm{NF}}{\mathrm{NI}}\right] \times 100 \%
$$

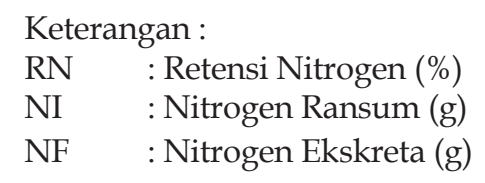

Metode penentuan kadar amonia dilakukan sesuai dengan Standar Nasional Indonesia (SNI) 2354.8 : 2009. Metode ini umumnya terdiri atas tahap ekstraksi, destilasi, dan titrasi. Pada proses penentuan kadar gas amonia ekskreta diekstrak menggunakan asam perklorat $6 \%$. Ekstrak yang didapat dimasukkan ke dalam tabung destilasi dan diteteskan indikator fenolftalein. Tabung destilasi dipasang pada peralatan destilasi uap dan kedalamnya ditambahkan larutan $\mathrm{NaOH}$ $20 \%$. Destilasi uap dilakukan selama kurang lebih 10 menit. Hasil destilasi ditampung dalam erlenmeyer yang berisi larutan $\mathrm{H}_{3} \mathrm{BO}_{4} 3 \%$ dan indikator Tashiro yang berwarna ungu. Hasil destilasi yang bercampur dengan larutan dalam erlenmeyer akan menghasilkan larutan yang berwarna hijau. Tahap berikutnya adalah destilasi larutan blanko dengan cara mengganti ekstrak sampel dengan PCA 6\%. Setelah itu destilat dari sampel dan blanko dititrasi menggunakan $\mathrm{HCl}$ 0,02 N sampai larutan berwarna ungu. Kadar gas amonia dihitung dengan menggunakan rumus:

$$
\begin{aligned}
\text { Total Nitrogen Volatile }= & ((\mathrm{Vc}-\mathrm{Vb}) \times \mathrm{N} \times 14,007 \\
& \times 2 \times 100) / \mathrm{W}
\end{aligned}
$$

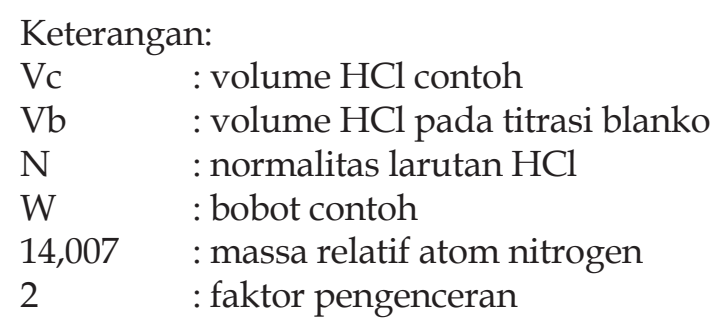

\section{Analisis data}

Data yang diperoleh dianalisis dengan analisis ragam (ANOVA) pada taraf 5\% untuk mengetahui pengaruh perlakuan. Apabila ada pengaruh yang signifikan maka dilanjutkan dengan Uji Duncan untuk mengetahui perbedaan antar perlakuan.

\section{HASIL DAN PEMBAHASAN}

\section{Nilai retensi nitrogen}

Berdasarkan data Tabel 2 menunjukkan bahwa pemberian ekstrak daun kepel dalam ransum dengan dosis $R_{1}(0,15 \%), R_{2}(0,30 \%)$ dan $R_{3}(0,45 \%)$ berpengaruh nyata terhadap nilai retensi nitrogen pada ayam broiler. Selain itu, perlakuan terbaik pemberian ekstrak daun kepel dalam ransum ayam broiler untuk meningkatkan nilai retensi nitrogen yaitu pada perlakuan $\mathrm{R}_{2}(0,30 \%)$ yang memiliki nilai rataan tertinggi $72,88 \pm 1,29$ dibandingkan perlakuan lainnya. Nilai retensi nitrogen terendah pada perlakuan $\mathrm{R}_{0}$ dapat disebabkan karena penyerapan zat makanan tidak optimal yang disebabkan oleh aktivitas dari bakteri patogen yang menghasilkan toksin untuk menghambat fungsi dari dinding usus halus dalam menyerap zat makanan.

Nilai retensi nitrogen tertinggi pada perlakuan $\mathrm{R}_{2}$ dapat terjadi karena proses penyerapan zat makanan yang optimal dalam

Tabel 2. Bahan pakan, persentase penggunaan dan kandungan nutrien pakan basal

\begin{tabular}{lcc}
\hline Perlakuan & $\begin{array}{c}\text { Retensi } \\
\text { Nitrogen }(\%)\end{array}$ & $\begin{array}{c}\text { Amonia Ekskreta } \\
(\mathrm{ppm})\end{array}$ \\
\hline R0 & $68,27 \pm 0,86^{\mathrm{a}}$ & $32,31 \pm 1,67^{\mathrm{a}}$ \\
R1 & $72,15 \pm 0,11^{\mathrm{bc}}$ & $17,89 \pm 4,51^{\mathrm{b}}$ \\
R2 & $72,88 \pm 1,29^{\mathrm{cd}}$ & $16,90 \pm 0,85^{\mathrm{cd}}$ \\
R3 & $71,47 \pm 2,36^{\mathrm{b}}$ & $17,77 \pm 0,31^{\mathrm{bc}}$ \\
\hline Keterangan : Nilai pada kolom yang sama dengan superskip \\
\multicolumn{2}{c}{$\begin{array}{l}\text { yang berbeda menunjukkan pengaruh yang berbeda } \\
\text { nyata (P<0,05). }\end{array}$}
\end{tabular}


usus halus, hal ini membuktikan bahwa pengaruh senyawa proantosianidin yang juga termasuk golongan senyawa flavonoid dalam ekstrak daun kepel berfungsi untuk mengurangi populasi bakteri gram positif yang bersifat patogen dan memberikan aktivitas proteksi pada dinding usus halus ayam broiler terhadap toksin yang dihasilkan oleh bakteri gram negatif. Flavonoid dapat meningkatkan koloni Bakteri Asam Laktat (BAL) sehingga laju digesta berjalan lebih lambat, lebih kental dan meningkatkan kecernaan dan retensi nitrogen meningkat (Reno, 2013). Senyawa tannin terkondensasi sebagai antibakteri juga dapat menghambat enzim reverse transkriptase dan DNA topoisomerase yang berperan dalam proses multiplikasi bakteri sehingga sel bakteri pathogen tidak dapat terbentuk dan memperbanyak diri (Mukhriani dkk, 2014).

\section{Kandungan amonia ekskreta}

Berdasarkan Tabel 2 menunjukkan bahwa pengaruh pemberian ekstrak daun kepel dalam ransum dengan dosis $R_{1}(0,15 \%), R_{2}(0,30 \%)$ dan $R_{3}(0,45 \%)$ berpengaruh nyata terhadap kandungan amonia ekskreta ayam broiler. Pemberian ekstrak daun kepel dalam ransum menghasilkan nilai kandungan amonia ekskreta yang lebih rendah yaitu pada perlakuan $R_{1}, R_{2}$ dan $\mathrm{R}_{3}$ dibandingkan ransum tanpa pemberian ekstrak daun kepel $\mathrm{R}_{0}$. Selain itu, perlakuan terbaik pemberian ekstrak daun kepel dalam ransum ayam broiler untukmenekan kandungan amonia eksreta ayam broiler yaitu pada perlakuan $\mathrm{R}_{2}(0,30 \%)$ yaitu $16,90 \pm 0,85$. Kadar amonia ekskreta ayam broiler yang aman yaitu berkisar antara 3-5 ppm, pada kadar 11 hingga $30 \mathrm{ppm}$ dapat menurunkan produktivitas dan menginfeksi saluran pernafasan dan pada kadar 35 ppm ke atas dapat mengakibatkan pembengkakan bursa fabricious hingga kematian (Pauzenga, 1991).

Flavonoid bekerja sebagai antibakteri melalui beberapa mekanisme, seperti mengintervensi membran sitoplasma; serta menghambat sintesis asam nukleat, metabolisme energi, sintesis dinding sel, dan sintesis membran sel (Tim and Lamb, 2005). Penurunan kadar amonia ekskreta terjadi karena pemberiaan ekstrak daun kepel yang mengandung senyawa proantosianidin atau turunan dari flavonoid. Senyawa proantosianidin berfungsi membunuh bakteri pathogen agar jumlahnya tidak berlebihan dalam usus halus ayam broiler. Hal tersebut akan mengoptimalkan penyerapan $\mathrm{N}$ pakan oleh tubuh, maka dari itu kandungan amonia ekskreta akan menurun atau dibawah ambang batas kadar amonia yang seharusnya.

\section{KESIMPULAN DAN SARAN}

\section{Kesimpulan}

Penambahan ekstrak daun kepel 0,30\% sebagai feed additive herbal dalam ransum meningkatkan nilai retensi nitrogen dan menurunkan kandungan amonia ekskreta ayam broiler pada akhir masa pemeliharaan.

\section{Saran}

Senyawa bioaktif dalam daun kepel perlu kajian lebih detail karena memiliki potensi besar sebagai antibakteri yang dapat menambahkan literasi keilmuan dan industri peternakan ayam broiler

\section{UCAPAN TERIMAKASIH}

Saya ucapkan terimakasih kepada staff Laboratorium Nutrisi Ternak Unggas Non Ruminansia dan Industri Makanan Ternak yaitu Jhondri, ST, Salman dan Suryaman Malik yang telah membantu dalam pelaksaan teknis selama penelitian.

\section{DAFTAR PUSTAKA}

Dwijoseputro. 2005. Dasar-Dasar Mikrobiologi. Djambatan, Jakarta.

Freund, R. J., W. J. Wilson, and D. L. Mohr. 2010. Data and Statistics. In Statistical Methods. Elsevier, Amsterdam.

Laboratorium Forensik. 2019. Analisis Zat Bioaktifdengan Menggunakan Alat LCMS. Puslabfor Polri, Jakarta.

Leeson, S., and J. D. Summers. 2005. Commercial Poultry Nutrition $3^{\text {rd }}$ Ed. Department of Animal and Poultry Science, University of Guelph, Ontario, Canada.

Maynard, L. A. and J. K. Loosli. 1962. Animal Nutrition. Fifth Edition. McGraw-Hill Book Co., New York.

Mukhriani, Nurlina, dan F. F. Baso. 2014. Uji aktivitas antimikroba dan identifikasi ekstrak buahsawo manila (Achraszapota L.) terhadap beberapa mikroba patogen dengan metode difusi agar. Jurnal Farmasi, 2(2): 69-74. 
Mukhriani, F. Y. Nonci, dan Mumang. 2014. Penetapan kadar tanin total ekstrak biji jintan hitam (Nigella sativa) secara spektrofotometri UV-VIS. Jurnal Farmasi, 4(4): 154-158.

Peters, C. J., and J. W. Peters. 1999. An introduction to Ebola: The virus and the disease. The Journal of Infectious Diseases. 179: 9-14.

Tim C.T., and A. J. Lamb. 2005. Antimicrobial activity of flavonoids. International Journal of Antimicrobial Agents, 26(5): 343-356.

Trevino, J., M. L. Rodriguez, L. T. Ortiz, A. Rebole, and C. Alzueta. 2000. Protein quality of linseed for growing broiler chicks. Animal Feed Science and Technology, 84(3-4): 155166.
Vince, A. J., and S. M. Burridge. 1980. Ammonia production by intestinal bacteria: The effects of lactose, lactulose and glucose. Journal of Medical Microbiology, 13(2): 177-191.

Reno, P. Z. 2013. Pengaruh Pemberian Probiotik Weisella paramesenteroides Isolat Dadiah sebagai Anti Diare pada Mencit (Musmuscullus). Disertasi. Universitas Andalas, Padang. 